\title{
Religijność i moralność polskiej młodzieży - zależność czy autonomia?
}

\section{Teorie przemian religijności: pomiędzy sekularyzacją i desekularyzacją}

ntensywne zmiany w sferze religijności obserwowane w Europie w drugiej połowie XX wieku skłoniły część socjologów religii do formułowania dość radykalnych tez o podążaniu w kierunku zaniku religii i marginalizacji jej wpływu zarówno na życie publiczne, jak i prywatne. „Prognozowano odchodzenie od zinstytucjonalizowanych form pobożności ku indywidualizacji i prywatyzacji przekonań religijnych lub nawet wybór areligijnego, laickiego modelu życia. Powoływano się na wyniki ilościowych badań w krajach zachodniej Europy, w której pustoszejące kościoły były jaskrawo widocznym przejawem malejącego znaczenia wspólnotowego kultu. Spadające wskaźniki religijnej identyfikacji i zaufania do instytucji kościelnej, kwestionowanie zwłaszcza religijnych norm obyczajowości rodzinnej i seksualnej utwierdzały badaczy w sekularyzacyjnych prognozach. Odwoływano się przy tym do tezy twórców myśli socjologicznej: Augusta Comte'a, Emila Durkheima i Maxa Webera o malejącej roli religii w epoce postępów modernizacyjnych"'.

Dr Rafa£ Boguszewski - Szkoła Główna Gospodarstwa Wiejskiego w Warszawie, Wydział Socjologii i Pedagogiki, Instytut Nauk Socjologicznych i Pedagogiki, adiunkt w Katedrze Socjologii, e-mail: rafal_boguszewski@sggw.pl, ORCID 0000-0002-1831-4265.

** Dr Marta Bożewicz - Uniwersytet Warszawski, Wydział Nauk Politycznych i Studiów Międzynarodowych, adiunkt w Katedrze Metodologii Badań nad Polityką, e-mail: marta.bozewicz@ gmail.com, ORCID: 0000-0002-0814-1815.

1 M. Libiszowska-Żółtkowska, Wprowadzenie, w: Pomiędzy sekularyzacją i religijnym ożywieniem, E. Firlit, M. Hainz, M. Libiszowska-Żółtkowska, G. Pickel, D. Pollack, Kraków 2012, s. 7. 
Powyższe prognozy nie znalazły jednakże jednoznacznego odzwierciedlenia w rzeczywistości, stąd przełom XX i XXI wieku skłonił część propagatorów teorii sekularyzacji, $w$ tym m.in. Petera Bergera (czołowego wyznawcę tej teorii $\mathrm{z}$ lat 70. XX wieku²) do zweryfikowania swoich tez. Zwolennicy teorii sekularyzacji w istotny sposób przedefiniowali pojęcie sekularyzacji: zamiast zaniku religii i religijności położono akcent na zmianę form życia religijnego. Jednakże $\mathrm{w}$ wielu przypadkach doprowadziło to do chaosu pojęciowego, posługiwania się rozbieżnymi definicjami sekularyzacji, poszerzania tego pojęcia tak, aby obejmowało ono zmiany, które we wcześniejszej definicji sekularyzacji nie były uwzględnione ${ }^{3}$. $Z$ drugiej strony ciężko jest na tyle poszerzać znaczenie sekularyzacji, aby obejmowało ono powstawanie nowych form religijności i duchowości. W tym kontekście mówi się wręcz o przeciwnym zjawisku - desekularyzacji czy też postsekularyzmu ${ }^{4}$ albo powrotu sacrum ${ }^{5}$. Proces ten ma się wyrażać m.in. w indywidualizacji religii, która sprawia, że religijność staje się religijnością z wyboru, bardziej osobistą, a przez to też bardziej autentyczną i pogłębioną ${ }^{6}$ a w niektórych ujęciach wręcz w bardziej masowym powrocie religii do społeczeństwa $w$ formie wzrostu znaczenia religijnych ruchów konserwatywnych, ortodoksyjnych i tradycjonalistycznych, odrzucających kompromisy z nowoczesnością i przystosowanie się do niej ${ }^{7}$ oraz w rozwoju nowych form duchowości i mistycyzmu ${ }^{8}$. Badania nowych ruchów religijnych, rozpoczęte przez klasyków teorii sekularyzacji, takich jak Bryan Wilson, prowadzą do niejednoznacznych wniosków. Niektórzy widzą w badanych zjawiskach potwierdzenie procesów sekularyzacji i - konsekwentnie - uważają ten nurt badań za integralną część teorii sekularyzacji, natomiast inni upatrują w nich świadectwa zmienności i żywotności religii, interpretując nowe ruchy religijne jako odpowiedź na wyzwania nowoczesności ${ }^{9}$.

Obecnie także Peter Berger, wcześniejszy popularyzator teorii sekularyzacji, zauważa tendencje desekularyzacyjne, jednocześnie jednak nie zaprzeczając procesom sekularyzacyjnym. Pisze m.in.: ,jest dla mnie oczywiste, że świat jest tak samo religijny, jak zawsze, a gdzieniegdzie nawet bardziej niż kiedykolwiek. Nie oznacza to jednakże, iż nie istnieje coś takiego jak sekularyzacja, tylko że

2 P. Berger, Święty baldachim. Elementy socjologicznej teorii religii, Kraków 2005.

3 S. Sztajer, Założeniowość teorii przemian religijności, „Przegląd Religioznawczy” 2015, nr 1(255), s. 122 .

J. Habermas, Wierzyć i wiedzieć, „Znak” 2002, nr 568, tłum. M. Łukasiewicz, s. 10.

D. Bell, Powrót sacrum, Poznań 1983, nr 346.

M. Grabowska, Bóg a sprawa polska. Poza granicami teorii sekularyzacji, Warszawa 2018, s. 83.

J. Mariański, Sekularyzacja i desekularyzacja w nowoczesnym świecie, Lublin 2006, s. 77.

M. Libiszowska-Żółtkowska, Religijność i duchowość - dawne i nowe formy, Kraków 2010.

M. Grabowska, Bóg a sprawa polska..., s. 11-12. 
zjawisko to w żadnym wypadku nie jest bezpośrednim i nieuchronnym skutkiem nowoczesności”'10.

Za procesami sekularyzacyjnymi przemawia to, że „w społeczeństwach ponowoczesnych zinstytucjonalizowana religia traci bezpośredni wpływ na życie społeczne, zwłaszcza zaś na życie polityczne. Także wiele decyzji jednostkowych nie mieści się w sferze zastrzeżonej dla sacrum. W wyjaśnianiu i interpretacji życia społecznego religia ma w nowoczesnych społeczeństwach wielu konkurentów, tym samym traci swoją dawną wiarygodność jako jedyne źródło sensu życia"”l. Z kolei argumenty antysekularyzacyjne wskazują na to, że religia nie znika w społeczeństwie, natomiast zmienia swoje społeczne formy jako rezultat transformacji społeczno-kulturowej. W tym kontekście - jak zauważa Janusz Mariański - przedwczesne byłoby określać współczesne społeczeństwa wysoko rozwinięte jako całkowicie zsekularyzowane. Czynnik religijny jest wciąż obecny w jakichś formach we wszystkich dziedzinach życia ludzkiego. Marzenia o dojrzałym humanizmie bez religii, z jakąś bliżej nieokreśloną duchowością, są mrzonką. Teoria sekularyzacji okazuje się niezdolna do wyjaśniania wielu faktów religijnych ${ }^{12}$.

Jak zatem widać, debaty na temat sekularyzacji i samej teorii sekularyzacji nie wygasają, ani tym bardziej nie stają się czymś drugorzędnym w socjologii religii. Wielu socjologów wciąż zajmuje się fenomenem religijnym $\mathrm{z}$ punktu widzenia teorii sekularyzacji, a zwolennicy tezy sekularyzacyjnej różnią się między sobą znacznie na płaszczyźnie teoretycznej (geneza sekularyzacji, jej formy i zróżnicowania) i empirycznej. Debaty toczą się między tymi, którzy wyrośli na gruncie teorii sekularyzacji, a tymi, którzy szukają nowych wyjaśnień postaw i zachowań religijnych w nowoczesnych społeczeństwach ${ }^{13}$. To, co dla jednych autorów jest przejawem desekularyzacji, dla innych daje się uzgodnić $\mathrm{z}$ teorią sekularyzacji. Co jednak istotne, $\mathrm{w}$ jednym i drugim przypadku nie jest kwestionowane to, że religijność się zmienia. Zmieniają się jej formy, oddziaływanie, a także jej wpływ na sferę norm i wartości.

\section{Możliwe związki między religijnością i moralnością}

W początkach socjologicznych rozważań teoretycznych dotyczących zależności pomiędzy systemem religijnym i moralnym nie pojawiało się pytanie o to, czy taki związek w ogóle występuje, ale co najwyżej o to, jaki jest jego kierunek.

10 P. Berger, Refleksje o dzisiejszej socjologii religii, „Teologia Polityczna” 2009-2010, nr 5, s. 91.

11 J. Mariański, Sekularyzacja a nowe formy religijności, „Roczniki Nauk Społecznych” 2009, t. 1(37), s. 34.

12 Tamże.

13 Tamże, s. 33. 
I tak na przykład August Comte przyjmował, że stadium teologiczne stanowi pierwszy etap w rozwoju moralnym społeczeństw, który to rozwój wiąże się z przejściem do stadium pozytywistycznego, natomiast Émil Durkheim traktował religię jako powstałą $z$ uświęcenia idei społecznych, a tym samym moralnych. Jeszcze inni sugerowali wzajemne oddziaływanie religii i moralności bez wskazywania na kierunek zależności. Obecnie tego typu oddziaływania nie są już tak oczywiste. Aktualne ujęcia relacji pomiędzy religią i moralnością obejmują ogromną skalę możliwości: od pełnej zgodności, poprzez częściową zgodność i częściową niezgodność, aż do przeciwstawności i sprzeczności ${ }^{14}$.

Skrajne ujęcia sugerują z jednej strony ścisłą zależność pomiędzy tymi dwoma wymiarami życia społecznego, a z drugiej całkowite ich odseparowanie. Zwolennicy pierwszego podejścia twierdzą, że religia nadaje wartościom i normom moralnym znaczenie powszechne i absolutne. Brak religijnego uzasadnienia grozi swoistą hipotetyzacją aksjologiczną moralności. Religia w tym ujęciu chroni moralną „substancję" społeczeństwa, spełnia wobec niego funkcje etyczno-krytyczne oraz przyczynia się do jego integracji normatywnej ${ }^{15}$. Przedstawiciele tego podejścia upatrują zatem w przejawach nasilającej się patologii społecznej bezpośredniego wpływu obniżenia się poziomu religijności społeczeństwa lub rozluźnienia bądź zerwania związków pomiędzy religią i moralnością. W ich przekonaniu bez religii grozi społeczeństwu anomia, a nawet chaos moralny ${ }^{16}$. W tym kontekście zwraca się uwagę, że wiara ma wymiar moralny, „jest źródłem zgodnego z nią życiowego zaangażowania i zarazem takiego zaangażowania się domaga" ${ }^{17}$. Z kolei drugie, opozycyjne podejście sugeruje zupełną autonomię pomiędzy tym, co religijne, a tym, co moralne. Propagatorzy tego ujęcia mówią o pełnej i doskonałej formie moralności dopiero wtedy, gdy uwolni się ona od wymogów sankcji religijnych oraz od nacisków autorytetów zewnętrznych i stanie się sprawą jednostki (gwarancja autonomii i suwerenności człowieka). Ich zdaniem religijne uzasadnienia nie są konieczne do akceptacji określonych wartości i norm moralnych. Co więcej, sankcjonowany przez religię tzw. wyższy autorytet stanowi zagrożenie dla indywidualnej autonomii i osądu jednostkowego, gwarantującego moralność bardziej dojrzałą i wolną, wyrastającą ze społecznego doświadczenia dobra i zła ${ }^{18}$.

14 J. Mariański, Socjologia moralności..., s. 410.

15 J. Mariański, Religia i moralność we wspótczesnym świecie - utożsamianie czy rozdzielanie?, w: Scio cui credidi. Księga pamiątkowa ku czci Księdza Profesora Mariana Ruseckiego w 65. rocznice urodzin, red. I.S. Ledwoń, K. Kaucha i in., Lublin 2007, s. 1210.

16 J. Mariański, Religia i moralność w przednowoczesnych i nowoczesnych społeczeństwach, w: O społeczeństwie, moralności i nauce. Miscellanea, red. W. Pawlik, E. Zakrzewska-Manterys, Warszawa 2008, s. 213.

17 Jan Paweł II, Encyklika «Veritatis splendor», $\mathrm{nr} 89$.

18 J. Mariański, Religia i moralność we wspótczesnym świecie..., s. 1210. 
Wydaje się jednak, że charakter związków pomiędzy religią i moralnością jest zdecydowanie bardziej złożony niż mogłyby to sugerować wyżej zaprezentowane podejścia. Oddziaływanie religii i moralności nie sposób uznać za jednoznaczne i bezwzględne, tym bardziej jako stosowalne do wszelkich typów moralności ${ }^{19}$, w każdej sytuacji, w każdym czasie i w każdym kontekście społeczno-kulturowym. Związek religii i moralności należy traktować jako niestabilny i niejednorodny, w związku z czym może się on różnić i rzeczywiście różni się w zależności od typu i stopnia rozwoju poszczególnych społeczeństw i społeczności ${ }^{20}$. Zgodnie z przekonaniem Talcotta Parsonsa: „rzeczywista sytuacja społeczna nigdy nie zgadza się dokładnie z systemem wartości, lecz odbiega od niego w mniejszym lub większym stopniu. [...] związek między orientacją religijną a kierunkami działania społecznego jest $\mathrm{z}$ istoty swej bardzo skomplikowany, a komplikacje te koncentrują się głównie wokół problematyki moralnej. Podstawowe staje się pytanie, czy obowiązki odpowiedzialnego członka społeczeństwa dają się pogodzić z zaangażowaniem religijnym; czasem bowiem konflikt między tymi dwiema sferami może stać się bardzo ostry. [...] Sam problem jest tym bardziej skomplikowany, im bardziej skomplikowane jest społeczeństwo, w którym dana jednostka żyje, i im intensywniejszy jest w tym społeczeństwie proces zmian, powodujący nieadekwatność starych schematów postępowania"21.

W sytuacji zaawansowania procesu modernizacji religijność „wyboru” coraz bardziej powszechna, staje się jednocześnie religijnością o mniej wyrazistych konsekwencjach moralnych. Coraz mniejsze znaczenie ma tzw. parametr konsekwencyjny wyznawanej wiary i deklarowanej religijności. Spójność postaw moralnych z zasadami wyznawanej religii nie wydaje się konieczna do zachowania równowagi psychicznej. Moralność zorientowana jest raczej na konsekwencje postępowania, a nie na zasady - $\mathrm{w}$ tym zasady religijne. „O ile w społecznościach tradycyjnych zwartość postaw moralnych wynikała przede wszystkim z podłoża religijnego, to współcześnie normy i zasady kierujące działaniami ludzi stają się - podobnie jak dogmaty wiary - polem procesów selekcjonowania, aprobaty względnie dezaprobaty społecznej w świadomości jednostek i grup społecznych"22.

Społeczeństwa ewoluują jednak w różnych dziedzinach i kierunkach, a wraz z tymi zmianami zmieniają się także powiązania pomiędzy religijnością i moralnością. Zmiany te nie muszą i, jak się okazuje, nie przyjmują identycznego kierunku. W jednych społeczeństwach związek ten słabnie, głównie jeżeli

19 W. Słomski, Człowiek pośród dylematów i wyzwań etycznych współczesności, Warszawa 2009, s. 327.

20 R. Boguszewski, Religijność i moralność w społeczeństwie polskim: zależność czy autonomia? Studium socjologiczne, Toruń 2012, s. 287.

21 T. Parsons, Struktura społeczna a osobowość, Warszawa 1969, s. 367.

22 J. Mariański, Religijność w procesie przemian, Warszawa 1991, s. 98. 
chodzi o kraje z kręgu kultury zachodnioeuropejskiej, w innych natomiast, jak chociażby w niektórych państwach islamskich, ulega wzmocnieniu. Jak jednak stwierdza Talcott Parsons, jest udowodnione, że na dłuższą metę orientacje religijne i związane z nimi wartości stanowią istotny czynnik określający zasadnicze wzory organizacji społecznejej.

Zmiany społeczno-kulturowe w Polsce sugerują raczej kierunek rozluźniania się więzi religijno-moralnych. Związane jest to między innymi z odchodzeniem Polaków od uczestnictwa w praktykach religijnych. Zjawisko to szczególnie widoczne jest w przypadku młodych obywateli, którzy coraz rzadziej wiążą swoje postępowanie z jakimś jednym, ściśle określonym systemem wartości.

$\mathrm{W}$ prezentowanym artykule, $\mathrm{w}$ oparciu o wyniki badań ilościowych, regularnie realizowanych przez Fundację Centrum Badania Opinii Społecznej na reprezentatywnych próbach ogólnopolskich, jak również bazując na wynikach badań uczniów ostatnich klas szkół ponadgimnazjalnych - cyklicznie realizowanych przez CBOS we współpracy z Krajowym Biurem ds. Przeciwdziałania Narkomanii, staramy się wskazać na kierunki zmian religijności i moralności młodych Polaków, a także przeanalizować związki między tymi dwoma wymiarami życia młodzieży w Polsce. Dysponując analogicznymi danymi dla ogółu dorosłych Polaków, wskażemy na specyfikę religijności i moralności młodzieży na tle całej dorosłej populacji. Mamy oczywiście na względzie, że stosunek do religii nierzadko zmienia się w toku psychospołecznego rozwoju. Inaczej w tym wymiarze funkcjonują jednostki kształtujące swoją tożsamość, które dopiero wchodzą w dorosłość, a inaczej te, które osiągnęły stabilizację życiową. Niemniej porównywalne dane dla tej samej kategorii wiekowej respondentów realizowane na przestrzeni lat pozwalają na monitorowanie ewentualnych trendów, na które wskazujemy w artykule w oparciu o wspomniane badania.

\section{Religia w systemie wartości polskiej młodzieży}

Zgodnie z wynikami ostatniego badania CBOS i KBPN (z 2018 roku) zrealizowanego wśród młodzieży kończącej edukację na poziomie szkół ponadgimnazjalnych życie zgodne z zasadami religijnymi plasuje się pod koniec listy dążeń i celów życiowych młodych Polaków (5\% wskazań) ${ }^{24}$. Osoby te rzadziej wskazują wyłącznie na zdobycie władzy politycznej i możliwość podejmowania ważnych decyzji w sferze gospodarczej. Na szczycie dążeń młodzieży niezmiennie znajduje się przyjaźń, rodzina i kariera zawodowa. Warto jednak zauważyć, że 20

23 Tamże, s. 367.

24 M. Grabowska, M. Gwiazda, Młodzież 2018, Opinie i Diagnozy nr 43, red. M. Grabowska, M. Gwiazda, Warszawa 2019, s. 68. 
lat wcześniej życie zgodne z zasadami religijnymi jako jeden z najistotniejszych celów życiowych młodzieży wskazywane było dwukrotnie częściej niż obecnie (spadek z 10\% w 1998 roku do 5\% w 2018 roku).

Życie religijne systematycznie traci na znaczeniu wśród młodych Polaków, a rola jemu przypisywana jest istotnie mniejsza niż wśród ogółu dorosłej populacji. Na pytanie: „Który z wymienionych rodzajów działalności stanowi obecnie treść Pana(i) życia codziennego? Czemu poświęca Pan(i) najwięcej czasu i energii?", zadane Polakom przez CBOS w październiku 2018 roku, życie religijne wymieniło 10\% ogółu dorosłych oraz jedynie 3\% młodzieży w wieku od 18 do 24 lat. O ile zatem w obrazie aktywności ogółu Polaków religijność stanowi tło, o tyle w przypadku najmłodszej kategorii badanych pozostaje ona na marginesie codziennego życia ${ }^{25}$. Co jednak istotne, znaczenie przypisywane religijności w codziennym życiu w ciągu ostatnich 30 lat wyraźnie zmniejszyło się w każdej kategorii wiekowej (wśród ogółu badanych z 17\% do 10\%), w tym jednak najbardziej w przypadku najmłodszej grupy respondentów (z 7\% do $3 \%)$. Aktualnie dla młodzieży najważniejsze jest wykształcenie, praca i rodzina, a w dalszej kolejności korzystanie z życia, aktywność fizyczna i udział w życiu kulturalnym, podczas gdy w całym społeczeństwie zdecydowanie priorytet ma życie rodzinne, a w następnej kolejności praca i ochrona zdrowia ${ }^{26}$.
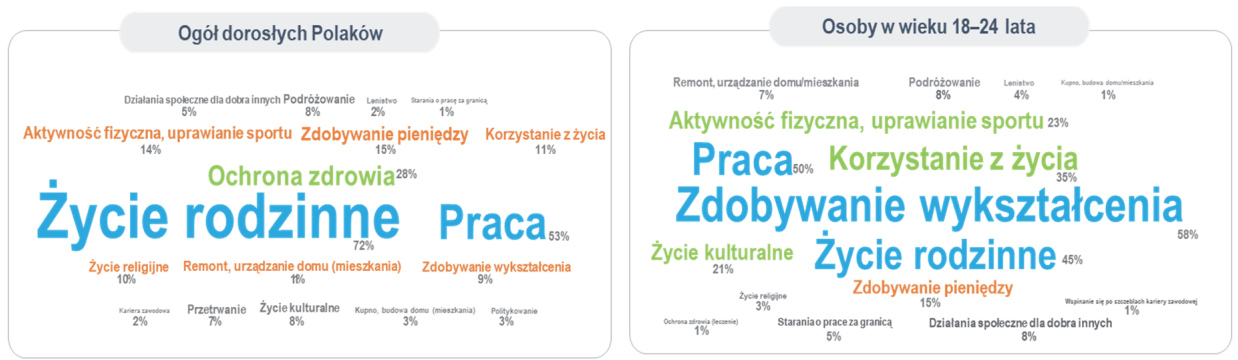

Rys. 1. Cele życiowe Polaków

Źródło: Opracowanie własne na podstawie: R. Boguszewski, Codzienna aktywność Polaków. Autoportret i obraz środowiska społecznego w latach 1988-2018, Komunikat z badań CBOS nr 164/2018.

25 R. Boguszewski, Codzienna aktywność Polaków. Autoportret i obraz środowiska społecznego w latach 1988-2018, Komunikat z badań CBOS nr 164/2018.

26 Tamże. 


\section{Religijność młodych Polaków}

Spadek odsetka młodych Polaków poświęcających swój czas życiu religijnemu koresponduje ze znaczącym wzrostem udziału osób niewierzących w grupie wiekowej 18-24 lata. Na przestrzeni ostatnich 10 lat w grupie tej liczba osób określających się jako niewierzące wzrosła ponad trzykrotnie (z 5\% w 2008 roku do 17\% w 2018 roku). W tym okresie wzrósł także udział obojętnych religijnie (z 13\% do $21 \%$ ), zmalała zaś istotnie liczba wierzących (z 73\% do 55\%). Co natomiast istotne, odsetek głęboko wierzących pozostaje stabilny (ok. 8\%) ${ }^{27}$. Patrząc zatem całościowo na przemiany wiary młodych ludzi w Polsce, można powiedzieć, że ulega ona pewnej polaryzacji przejawiającej się w istotnym wzroście odsetka niewierzących przy stabilnej liczbie głęboko wierzących. Młodzi ludzie istotnie odbiegają pod tym względem od ogółu dorosłych Polaków, spośród których znakomita większość (85\%) określa się mianem wierzących, przy relatywnie niewielkiej liczbie indyferentnych (5\%) i niewierzących (3\%) $)^{28}$.

Aby spróbować zrozumieć kim są młodzi niewierzący i niezdecydowani w kwestii wiary, można porównać ich odpowiedzi na pytanie: „Które z poniższych stwierdzeń dotyczących wiary w Boga jest Ci najbliższe?”. Wśród identyfikujących się jako niewierzący dominująca jest odpowiedź wskazująca na ateizm - „Nie wierzę w Boga” (59\%). Ponad jedna piąta badanych z tej grupy to de facto agnostycy, wybierający odpowiedź: „Nie wiem, czy Bóg istnieje, i nie wierzę, że jest sposób, aby to sprawdzić" (22\%). Kolejne 15\% nie wierzy w osobowego Boga, ale wierzy w pewnego rodzaju Siłę Wyższą, natomiast pozostałe 4\%, pomimo ogólnej deklaracji niewiary, wybiera stwierdzenia charakterystyczne dla wierzących. Z kolei wśród identyfikujących się jako niezdecydowani religijnie nie ma jednej dominującej opinii. Niemal co trzeciej osobie z tej grupy czasami wydaje się, że wierzy w Boga, a czasami, że nie wierzy (31\%), co czwartej najbliższe jest stwierdzenie opisujące postawę agnostyczną (25\%), co piąta nie wierzy w osobowego Boga, ale wierzy w Siłę Wyższą (19\%), a niewiele mniej twierdzi, że de facto wierzy w Boga, choć ma niekiedy chwile zwątpienia (15\%). Tylko $3 \%$ w tej grupie stanowią respondenci, którym najbliższe jest stwierdzenie: „nie wierzę w Boga", a $6 \%$ dla odmiany nie ma wątpliwości co do istnienia Boga. O ile więc młodzi określający się jako niewierzący to najczęściej ateiści, a w drugiej kolejności agnostycy, o tyle wśród niezdecydowanych można wyróżnić kilka różnych postaw wobec Boga występujących podobnie często, co oznacza, że jest to grupa zróżnicowana i trudna do jednoznacznego opisania.

27 M. Grabowska, M. Gwiazda, Młodzież 2018, Opinie i Diagnozy nr 43, red. M. Grabowska, M. Gwiazda, Warszawa 2019, s. 148.

28 Na podstawie badania CBOS „Aktualne problemy i wydarzenia” nr 353 z października 2018, a więc w analogicznym czasie do realizacji badania młodzieży - dla zachowania porównywalności wyników. 
Tabela 1. Deklaracje wiary

\begin{tabular}{|l|c|c|c|c|}
\hline \multirow{2}{*}{$\begin{array}{c}\text { Które z poniższych stwierdzeń } \\
\text { dotyczących wiary w Boga } \\
\text { jest Ci najbliższe? }\end{array}$} & \multicolumn{4}{|c|}{$\begin{array}{c}\text { Niezależnie od udziału w praktykach religijnych, } \\
\text { czy uważasz się za osobę: }\end{array}$} \\
\cline { 2 - 5 } & $\begin{array}{c}\text { głęboko } \\
\text { wierzącą }\end{array}$ & wierzącą & niezdecydowaną & niewierzącą \\
\cline { 2 - 5 } & \multicolumn{4}{|c|}{ w procentach } \\
\hline $\begin{array}{l}\text { Wierzę w Boga i nie mam co do Jego } \\
\text { istnienia wątpliwości }\end{array}$ & 83 & 54 & 6 & 2 \\
\hline $\begin{array}{l}\text { Wierzę w Boga, choć mam niekiedy } \\
\text { chwile zwątpienia }\end{array}$ & 13 & 34 & 15 & 0 \\
\hline $\begin{array}{l}\text { Czasami wydaje mi się, że wierzę } \\
\text { w Boga, a czasami, że nie wierzę }\end{array}$ & 0 & 8 & 31 & 2 \\
\hline $\begin{array}{l}\text { Nie wierzę w osobowego Boga, ale } \\
\text { wierzę w pewnego rodzaju Siłę Wyższą }\end{array}$ & 2 & 3 & 19 & 15 \\
\hline $\begin{array}{l}\text { Nie wiem, czy Bóg istnieje, i nie wierzę, } \\
\text { że jest sposób, aby to sprawdzić }\end{array}$ & 2 & 1 & 25 & 22 \\
\hline Nie wierzę w Boga & 1 & 0 & 3 & 100 \\
\hline Ogółem & 100 & 100 & 100 & 59 \\
\hline
\end{tabular}

Źródło: Opracowanie własne na podstawie badania CBOS „Młodzież 2018”.

Najczęściej stosowana jako wskaźnik religijności częstość praktyk religijnych ukazuje kolejny ważny wymiar przemian religijności młodych Polaków. Od 2008 roku prawie potroiła się liczba osób w wieku 18-24 lata deklarujących, że w ogóle nie uczestniczą w praktykach religijnych, takich jak msze, nabożeństwa lub spotkania religijne (wzrost z 16\% do 35\% w 2018 roku). Jednocześnie odsetek osób uczestniczących w nich kilka razy w tygodniu utrzymuje się na w miarę stałym poziomie od 1996 roku (ok. 7\%). Znacząco zmalał natomiast udział praktykujących co niedzielę (z 55\% w 1996 roku do 28\% w 2018 roku) przy dosyć stabilnym odsetku młodych osób uczestniczących w obrzędach religijnych kilka razy w roku (ok. 20\%). Potwierdza to wcześniejszą tezę o polaryzacji postaw religijnych wśród młodzieży, widoczną również w odniesieniu do ogółu dorosłych. Trzeba przy tym odnotować, że deklarowany udział młodzieży w praktykach religijnych wyraźnie odbiega od notowanego dla całej dorosłej populacji. Odsetek praktykujących regularnie (przynajmniej raz w tygodniu) jest wśród młodych o 15 punktów procentowych niższy niż wśród ogółu badanych (35\% wobec 55\%), natomiast liczba niewierzących niemal trzykrotnie wyższa (35\% wobec $12 \%)$. 
Co ciekawe, spadek udziału wierzących w populacji młodych Polaków na przestrzeni ponad dwudziestu lat ma taką samą dynamikę jak trend dotyczący praktykowania przynajmniej raz w tygodniu, natomiast wzrost udziału niewierzących nie przystaje ściśle do linii trendu dotyczącego całkowitego niepraktykowania. Ta druga linia rośnie szybciej, co oznacza, że młodzi ludzie najpierw przestają uczęszczać do kościoła, a dopiero potem zaczynają się identyfikować jako niewierzący. Wciąż jednak zdeklarowani jako niewierzący stanowią połowę niższy odsetek niż niepraktykujący. Inaczej mówiąc, odchodzenie od praktyk religijnych często nie oznacza odchodzenia od wiary. Dodatkowo warto przypomnieć, że nie wszyscy, którym najbliższe jest określenie „niewierzący” zdecydowanie odrzucają Boga. Jedna piąta z nich to agnostycy, a dodatkowe 19\% de facto uznaje istnienie jakiejś transcendencji. Wszystkie te analizy pozwalają dostrzec jak niejednorodna jest grupa młodych Polaków podlegających procesowi sekularyzacji. Największą grupę wśród nich stanowią niepraktykujący religijnie, o połowę mniej liczni są niewierzący, a spośród nich faktycznie tylko trzy piąte wyraża stanowcze przekonanie, że Bóg nie istnieje.

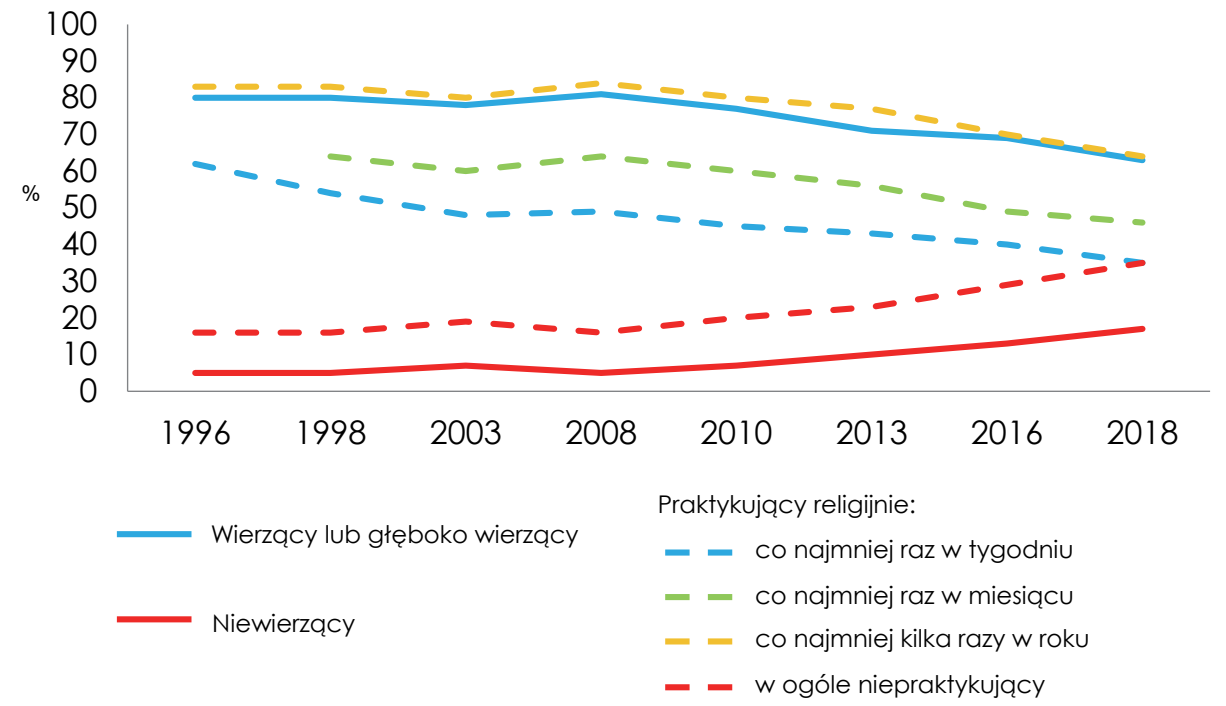

Rys. 2. Deklaracje wiary i praktyk religijnych

W kategorii „co najmniej raz w tygodniu” połączono odpowiedzi „kilka razy w tygodniu” i „raz w tygodniu".

W kategorii „,co najmniej raz w miesiącu” połączono odpowiedzi „kilka razy w tygodniu”, „raz w tygodniu” i „przeciętnie jeden, dwa razy w miesiącu”.

W kategorii „co najmniej kilka razy w roku” połączono odpowiedzi „kilka razy w tygodniu”, „raz w tygodniu”, , „przeciętnie jeden, dwa razy w miesiącu” i „kilka razy w roku”.

Źródło: Opracowanie własne na podstawie cyklicznych badań młodzieży realizowanych przez CBOS i KBPN. 
Z kolei młodzi głęboko wierzący, w zestawieniu deklaracji wiary i częstości praktyk religijnych, ujawniają się jako zdecydowanie ponadprzeciętnie religijni. Prawie dwie piąte osób w tej grupie uczęszcza na msze, nabożeństwa lub spotkania religijne kilka razy w tygodniu, a niewiele mniej (37\%) raz w tygodniu, podczas gdy dla przykładu wśród osób określających się jako wierzące chodzący do kościoła częściej niż raz w tygodniu stanowią mniej niż jedną dziesiątą. Zatem młodzi ludzie, którzy uważają się za głęboko wierzących, istotnie różnią się od wierzących w zakresie częstości praktyk religijnych, co potwierdza, że w ich przypadku za deklaracjami idą konkretne działania. Podobnie jest w przypadku osób ulokowanych na drugim krańcu skali, które określają się mianem niewierzących - konsekwentnie, w zdecydowanej większości, w ogóle nie uczestniczą w mszach, nabożeństwach i spotkaniach religijnych (84\%). Tylko nielicznym z nich zdarza się od czasu do czasu praktykować religijnie. Należy więc stwierdzić, że identyfikacje młodych ludzi z wiarą są świadome i zakorzenione w praktykach, co sprawia, że oba wymiary religijności są ze sobą wewnętrznie dość spójne.

Tabela 2. Wiara a praktyki

\begin{tabular}{|l|c|c|c|c|}
\hline \multirow{2}{*}{$\begin{array}{c}\text { Czy bierzesz udział w praktykach } \\
\text { religijnych, takich jak msze, } \\
\text { nabożeństwa lub spotkania } \\
\text { religijne? }\end{array}$} & \multicolumn{4}{|c|}{$\begin{array}{c}\text { Niezależnie od udziału w praktykach religijnych, } \\
\text { czy uważasz się za osobę: }\end{array}$} \\
\cline { 2 - 5 } & $\begin{array}{c}\text { głęboko } \\
\text { wierzącą }\end{array}$ & wierzącą & niezdecydowaną & niewierzącą \\
\cline { 2 - 5 } & \multicolumn{5}{|c|}{ w procentach } \\
\hline Tak, kilka razy w tygodniu & 39 & 7 & 1 & 2 \\
\hline Tak, raz w tygodniu & 37 & 40 & 14 & 3 \\
\hline $\begin{array}{l}\text { Tak, przeciętnie jeden, dwa razy } \\
\text { w miesiącu }\end{array}$ & 12 & 14 & 13 & 3 \\
\hline Tak, kilka razy w roku & 7 & 20 & 26 & 84 \\
\hline W ogóle w nich nie uczestniczę & 5 & 19 & 46 & 100 \\
\hline Ogółem & 100 & 100 & 100 & 8 \\
\hline
\end{tabular}

Źródło: Opracowanie własne na podstawie badania CBOS Młodzież 2018.

Co jednak istotne, o ile deklaracje wiary ogółu Polaków po nieznacznych spadkach ustabilizowały się i od 2011 roku pozostają na porównywalnym poziomie (odsetek niewierzących waha się między 7\% a 8\%), o tyle w przypadku młodych Polaków odsetek niewierzących wzrósł w latach 2011-2018 z 12\% do $23 \%$, w tym najbardziej dynamiczny wzrost odnotowany został w ostatnich la- 
tach. Taka sama tendencja dotyczy praktyk religijnych. Zmiany w tym zakresie są wyraźnie bardziej widoczne wśród osób w wieku od 18 do 24 lat niż wśród ogółu dorosłych Polaków, gdzie spadki również są obserwowane, ale są one istotnie mniej dynamiczne (patrz wykresy 3-5).

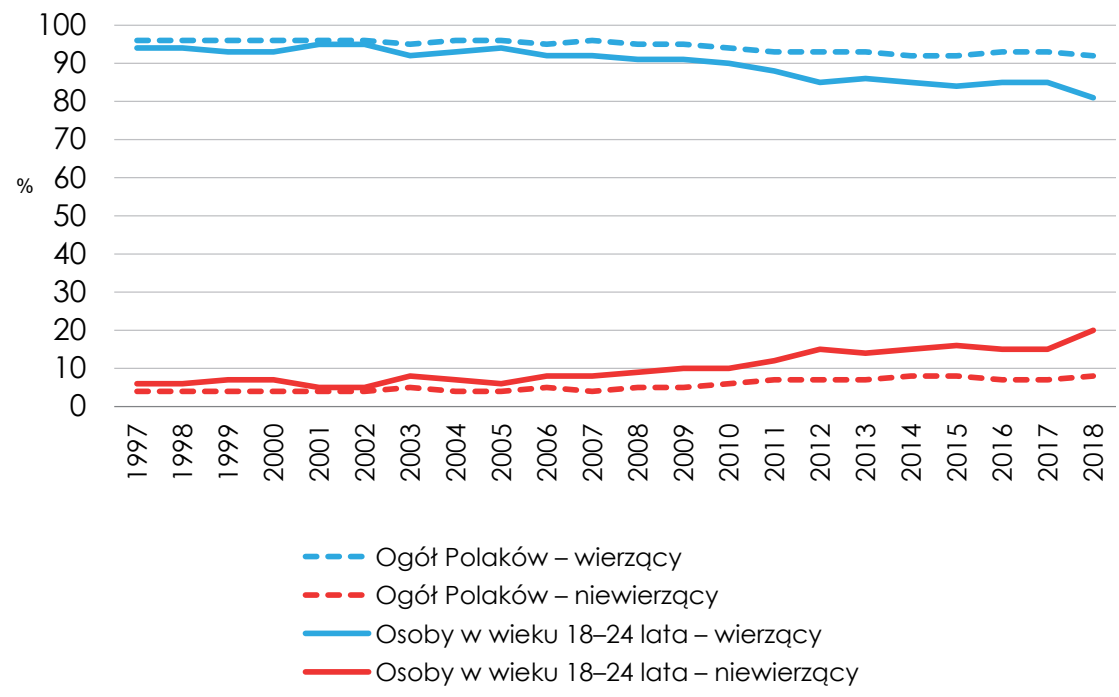

Rys. 3. Wiara młodzieży i ogółu dorosłych Polaków

Źródło: Opracowanie własne na podstawie cyklicznych badań CBOS.

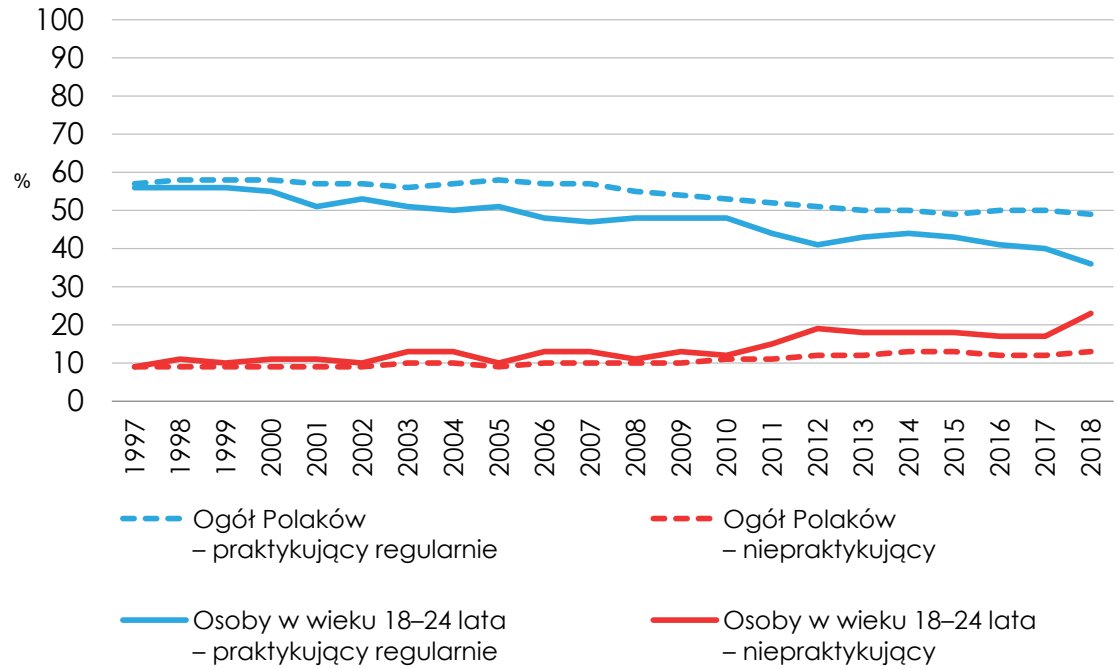

Rys. 4. Praktyki młodzieży i ogółu dorosłych Polaków

Źródło: Opracowanie własne na podstawie cyklicznych badań CBOS. 


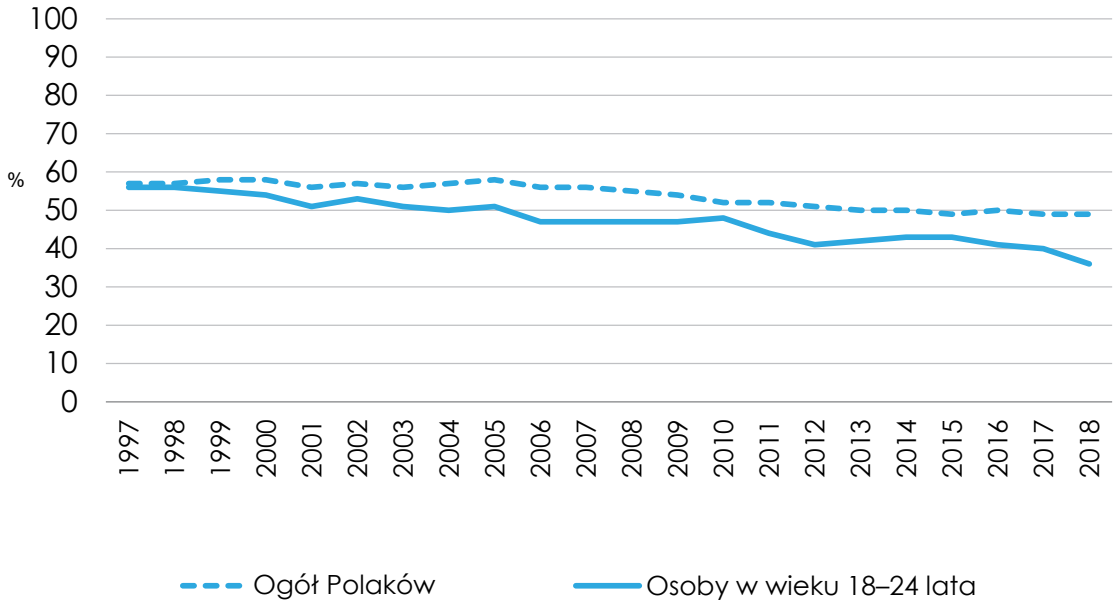

Rys. 5. Wiara i praktyki: młodzież i ogół dorosłych Polaków

Źródło: Opracowanie własne na podstawie cyklicznych badań CBOS.

Podkreślenia wymaga fakt, że religijność młodzieży przyjmuje tożsamy trend bez względu na miejsce zamieszkania, natomiast deklaracje niewiary i nieuczestniczenie w praktykach religijnych są wyraźnie częstsze w przypadku młodzieży wielkomiejskiej niż pochodzącej ze wsi i małych miast. Prawidłowość ta dotyczy również deklaracji uczęszczania na lekcje religii. W ciągu dziesięciu lat odsetek uczniów ostatnich klas szkół ponadgimnazjalnych uczestniczących w katechezie zmniejszył się z 91\% w 2008 roku do 70\% w 2018 roku, przy czym o ile na wsiach nieuczęszczanie na lekcje religii deklaruje $22 \%$ badanych uczniów, o tyle w największych aglomeracjach odsetek ten sięga aż 56\%. Różnice te, jak można się domyślać, wynikają między innymi z ciągle różnego poziomu kontroli społecznej w zależności od wielkości miejscowości zamieszkania. Warto też dodać, że znaczący wzrost odsetka młodych nieuczęszczających na lekcje religii nastąpił dopiero po 2013 roku. Wcześniej udział w katechezie był niemal powszechny, pomimo postępującej sekularyzacji, o której świadczą powyżej omówione trendy w zakresie religijności młodzieży.

Religijność młodych Polaków ewidentnie wykazuje tendencje sekularyzacyjne, zmierzając raczej w kierunku dezinstytucjonalizacji, indywidualizacji i prywatyzacji, o czym świadczy to, że spadek udziału w praktykach religijnych jest istotnie mniej radykalny niż deklaracje wiary, młodzież nie jest jakoś wyjątkowo krytyczna w ocenie działalności Kościoła katolickiego na tle całej populacji ${ }^{29}$,

29 A. Głowacki, Oceny sytuacji Kościoła katolickiego w Polsce, Komunikat z badań CBOS nr 101/2019. 
a chrześcijańskie tradycje świąteczne ${ }^{30}$ praktykuje dość powszechnie i w zakresie porównywalnym do ogółu Polaków. Jednocześnie jednak, podobnie jak ogół populacji, młodzi ludzie oba główne święta chrześcijańskie traktują raczej jako wydarzenia o charakterze rodzinnym niż religijnym, a obrzędy religijne pielęgnują przede wszystkim $\mathrm{z}$ uwagi na tradycję. Należy mieć jednak na uwadze grupę młodych wykazujących się ponadprzeciętną religijnością, która od lat utrzymuje się na zbliżonym poziomie (ok. 8\%). Ich religijność ma w znacznej mierze charakter zinstytucjonalizowany, aczkolwiek jest przy tym pogłębiona i konsekwentna.

\section{Moralność młodych ludzi w Polsce}

Procesowi prywatyzacji i indywidualizacji religijności polskiej młodzieży towarzyszą podobne zmiany w wymiarze moralnym. W tej sferze są one być może nawet jeszcze bardziej wyraźne niż w przypadku różnych przejawów religijności. Młodych ludzi charakteryzuje najbardziej liberalne ze wszystkich grup wiekowych podejście do rozmaitych kwestii moralnych, takich jak: przerywanie ciąży, ściąganie na egzaminach, zaniedbywanie swoich obowiązków w pracy, jazda na gapę, wręczanie i przyjmowanie łapówek, przekraczanie dozwolonej prędkości, zdrada, rozwód, antykoncepcja, życie w związku bez ślubu itp. Skonstruowany na podstawie stosunku do ww. kwestii wskaźnik liberalizmu moralnego mierzony na siedmiopunktowej skali w grupie wiekowej 18-24 lata przyjmuje wartość istotnie wyższą niż w pozostałych kategoriach wiekowych Polaków, a jednocześnie cechuje się najmniejszym odchyleniem standardowym. Oznacza to, że młodzi są najbardziej liberalni w kwestiach moralnych i na tle innych grup wiekowych mają stosunkowo najbardziej zbieżne poglądy w tym względzie (patrz tabela 3).

Mając na uwadze sferę seksualną, widać, że liberalne podejście młodych do seksualności nie pojawiło się w ostatnim czasie, ale można je obserwować już od przeszło 20 lat. W 1998 roku prawie trzy czwarte młodzieży deklarowało, że „to zupełnie normalne, że kochający się ludzie utrzymują ze sobą kontakty seksualne, ślub nie jest do tego konieczny" (73\%). W badaniu z 2016 roku odsetek osób zgadzających się z tym stwierdzeniem wzrósł do 77\%. Podobnie jeśli chodzi o pierwsze kontakty seksualne młodych - zdecydowana większość jest przekonana, że nie trzeba z nimi czekać do momentu zawarcia małżeństwa (70\%). W 1998 roku taki pogląd deklarowało 65\% badanej młodzieży, a 17\% było przeciwnego zdania. W 2016 roku ze stwierdzeniem, że: „Pierwsze kon-

30 M. Bożewicz, Boże Narodzenie 2019, Komunikat z badań CBOS nr 164/2019. 
takty seksualne młodzi ludzie powinni mieć dopiero po zawarciu małżeństwa” zgadzało się jedynie $11 \%$ osób $^{31}$.

Tabela 3. Wskaźnik liberalizmu moralnego a wiek

$\begin{array}{ccc}\text { Wiek } & \text { Średnia* }^{*} & \text { Odchylenie standardowe } \\ \mathbf{1 8 - 2 4} \text { lata } & \mathbf{3 , 0 7} & \mathbf{0 , 7 6} \\ 25-34 & 2,30 & 0,78 \\ 35-44 & 2,94 & 0,79 \\ 45-54 & 2,77 & 0,83 \\ 55-64 & 2,56 & 0,83 \\ 65 \text { lat i więcej } & 2,38 & 0,94 \\ \text { Ogółem } & \mathbf{2 , 8 0} & \mathbf{0 , 8 5}\end{array}$

Źródło: Opracowanie własne na podstawie R. Boguszewski, Wartości i normy, komunikat z badań CBOS nr 111/2013.

* Przeciętna wartość wskaźnika „liberalizmu moralnego” mierzonego na skali 1-7. Wskaźnik skonstruowany poprzez zliczanie przyzwolenia na szereg różnych zachowań kontrowersyjnych etycznie, takich jak: bicie dzieci, przerywanie ciąży, ściąganie na egzaminach, zaniedbywanie swoich obowiązków w pracy, wręczanie i przyjmowanie łapówek, przekraczanie dozwolonej prędkości, jazda na gapę, zdradza, rozwód, antykoncepcja, życie w związku bez ślubu itp.

Zatem sekularyzacja moralności w kwestiach seksualnych jest wśród młodzieży od wielu lat daleko posunięta i postępuje już tylko nieznacznie, gdyż rozpoczęła się wyraźnie wcześniej niż spadek religijności młodych Polaków. Tym bardziej świadczy to o istotnym rozdzieleniu wymiaru moralnego i religijnego. Paradoksalnie, na skutek istotnego spadku religijności, aktualna zależność pomiędzy praktykami religijnymi oraz stosunkiem do zjawisk i zachowań o charakterze moralnym jest wyższa, gdyż oba typy postaw są obecnie bardziej spójne. Deklarowane postawy moralne są też dość spójne z zachowaniami młodzieży. Zgodnie z deklaracjami uczniów ostatnich klas szkół ponadgimnazjalnych (mających 18-19 lat) inicjację seksualną ma za sobą 54\% z nich, a średni wiek tej inicjacji wyniósł (na podstawie deklaracji) około 17 lat. Ci z młodych ludzi, którzy przyznają się do aktywności seksualnej, jednocześnie w zdecydowanej większości deklarują stosowanie środków antykoncepcyjnych ${ }^{32}$.

O sekularyzacji moralności świadczy też fakt, że osoby w wieku 18-24 lata chętniej niż starsi przyznają kobietom prawo do aborcji w rozmaitych sytuacjach. Tylko co dziesiąty badany uczeń w wieku 18-19 lat sprzeciwia się przerwaniu

31 M. Grabowska, M. Gwiazda, Młodzież 2016, Opinie i Diagnozy nr 38, red. M. Grabowska, M. Gwiazda, Warszawa 2019, s. 166.

32 Tamże, s. 169. 
ciąży gdy zagrożone jest życie matki (10\%), mniej więcej co szósty gdy ciąża jest wynikiem gwałtu lub kazirodztwa (17\%), co piąty gdy zagrożone jest zdrowie matki (21\%), a co trzeci gdy wiadomo, że dziecko urodzi się upośledzone (36\%). Dwie trzecie młodych ludzi uważa, że przerywanie ciąży nie powinno być dopuszczone przez prawo gdy kobieta po prostu nie chce mieć dziecka (63\%), znajduje się w trudnej sytuacji materialnej (65\%) lub osobistej $(66 \%)^{33}$. Dla porównania wśród ogółu dorosłych Polaków odsetki te sięgają około $80 \%{ }^{34}$. Dodatkowo warto zauważyć, że od 2016 do 2018 roku wzrosło wśród młodych Polaków poparcie dla dopuszczenia przez prawo przerywania ciąży z powodów osobistych, tzn. trudnej sytuacji materialnej kobiety lub jej niechęci do posiadania dziecka. Można zatem wnioskować, że aktualne młode pokolenie częściej niż starsze optuje za złagodzeniem prawa do aborcji, co tylko potwierdza rosnący liberalizm moralny młodzieży, zwłaszcza w wymiarze seksualno-rodzinnym.

\section{Religijność i/a moralność: sekularyzacja moralności?}

Jak wynika z zaprezentowanych powyżej danych empirycznych, postępującej sekularyzacji, a może raczej indywidualizacji religijności towarzyszy także sekularyzacja moralności, przejawiająca się uznawaniem za dopuszczalne zachowań sprzecznych z nauczaniem Kościoła. Wprawdzie omówione wcześniej opinie młodych na poruszone kwestie ze sfery seksualno-rodzinnej mają istotny statystycznie związek z ich religijnością, jednak - mimo to - w znacznej mierze pozostają ze sobą w konflikcie. Wprawdzie wśród praktykujących religijnie kilka razy w tygodniu ponad połowa zgadza się ze stwierdzeniem, że pierwsze kontakty seksualne młodzi ludzie powinni mieć dopiero po zawarciu związku małżeńskiego (56\%), jednak w grupie uczęszczających na msze, nabożeństwa i spotkania religijne raz w tygodniu odsetek ten sięga już zaledwie 16\%, a wśród rzadziej praktykujących nie przekracza 5\%. Podobną zależność obserwujemy w opiniach wobec stwierdzenia, że to zupełnie normalne, iż kochający się ludzie utrzymują ze sobą kontakty seksualne, a ślub nie jest do tego konieczny. Młodzi praktykujący kilka razy w tygodniu częściej nie zgadzają się z tym stwierdzeniem (53\%), niż zgadzają z nim (34\%), natomiast już wśród chodzących do kościoła raz w tygodniu z powyższym poglądem utożsamia się aż dwie trzecie badanych. Młodzi praktykujący nieregularnie niemal powszechnie (84\% i więcej) przyznają, że ślub nie jest warunkiem utrzymywania kontaktów seksualnych ${ }^{35}$.

33 M. Grabowska, M. Gwiazda, Młodzież 2018..., s. 165.

34 A. Głowacki, Jakiego prawa aborcyjnego oczekują Polacy?, Komunikat z badań CBOS nr 144/2016.

35 M. Grabowska, M. Gwiazda, Młodzież 2016..., s. 166. 
Częstość praktyk religijnych istotnie różnicuje także opinie o aborcji - zwłaszcza te dotyczące skrajnych przypadków. W sytuacji kiedy kobieta po prostu nie chce mieć dziecka, sprzeciw wobec dopuszczalności aborcji wyraża większość biorących udział w mszach, nabożeństwach lub spotkaniach religijnych przynajmniej raz w tygodniu (ok. 75\%). Badani rzadziej praktykujący są istotnie mniej radykalni w tym względzie, a w ogóle nieuczestniczący w praktykach religijnych częściej twierdzą, że w przedstawionej sytuacji aborcja powinna być dopuszczona przez prawo (37\%), niż zdecydowanie się temu sprzeciwiają (34\%). Związek postaw wobec aborcji z religijnością ujawnia się także ze względu na deklarowaną wiarę i niewiarę. I tak młodzi uważający się za głęboko wierzących w zdecydowanej większości sprzeciwiają się aborcji, gdy kobieta po prostu nie chce mieć dziecka (78\%), a niewierzący częściej ją popierają (47\%), niż są przeciwnego zdania (43\%). Pośrodku znajdują się niezdecydowani odnośnie własnej wiary, którzy w większości są przeciwko aborcji na życzenie (60\%), ale ponad jedna czwarta dopuszcza legalność aborcji w takiej sytuacji $(26 \%)^{36}$.

Choć zatem religijność nie pozostaje bez wpływu na postawy moralne młodzieży, to związek ten jest w znacznej mierze ograniczony i dotyczy głównie bardziej radykalnych kwestii. Młodzi ludzie w sposób uświadomiony w ocenie rzeczywistości bazują raczej na własnych osądach, niż kierują się nauczaniem Kościoła, a źródła zasad coraz częściej upatrują w sobie niż w jakichkolwiek autorytetach i regulacjach.

W 2005 roku mniej niż połowa młodych ludzi ankietowanych przez CBOS identyfikowała się ze stwierdzeniem, że to, czym jest dobro i zło, powinno być przede wszystkim wewnętrzną sprawą każdego człowieka (46\%). Ponad jedna czwarta badanych była przekonana, że powinny o tym decydować przede wszystkim prawa Boże (28\%), a niewiele mniej zgadzało się ze stwierdzeniem, że to społeczeństwo jest głównym wyznacznikiem moralności. Na przestrzeni lat spadał jednak udział tych dwóch opinii na rzecz przekonania, że rozstrzygający jest wewnętrzny głos każdego człowieka. W 2016 roku przekonanych o tym było już 70\% młodych osób, a tylko 8\% utrzymywało, że o dobru i złu rozstrzygają prawa Boże. Wśród ogółu dorosłych Polaków odsetek takich stwierdzeń okazał się wówczas dwa razy wyższy (15\%).

Inne pytanie o związki religii z moralnością, które CBOS w miarę regularnie zadaje Polakom, brzmi: „Na temat wzajemnego stosunku między religią a moralnością można spotkać wiele różnych poglądów. Który z przytoczonych jest najbliższy Pana(i) poglądom?”. Prawie połowa (48\%) młodych odpowiada na nie, że nie czuje potrzeby uzasadniania moralności przez religię, wystarczy im bowiem własne sumienie. Jeszcze siedem lat wcześniej ta odpowiedź była najbliższa tylko co trzeciej młodej osobie (33\%). Największy odsetek osób

\footnotetext{
36 Tamże, s. 172.
} 
Osoby w wieku 18-24 lata

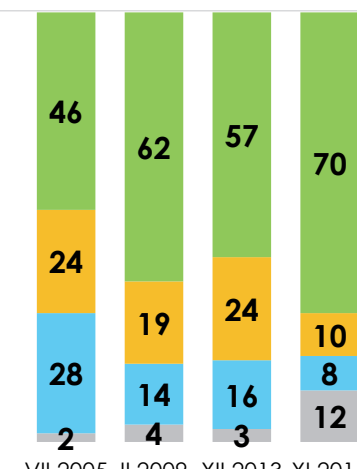

VII 2005 || 2009 XII 2013 XI 2016

$\mathrm{N}=155 \quad \mathrm{~N}=160 \quad \mathrm{~N}=105 \quad \mathrm{~N}=79$

Ogół Polaków

Rys. 6. Które ze stwierdzeń jest najbliższe Pana(i) opinii?

Źródło: Opracowanie własne na podstawie R. Boguszewski, Zasady moralne a religia, Komunikat $\mathrm{z}$ badań CBOS nr 4/2017.

identyfikował się wówczas ze stwierdzeniem: „dla mnie religia uzasadnia moje reguły moralne, ale sądzę, że można je sobie uzasadniać i bez niej” (51\%). Obecnie ten pogląd podziela $38 \%$ młodych, a więc moralność stała się w dość krótkim czasie znacznie bardziej indywidualną kwestią, na którą religia może wprawdzie wpływać, ale młodzież coraz częściej wpływu tego nie potrzebuje. Udział osób, które twierdzą, że tylko religia może uzasadniać słuszne nakazy moralne jest równy odsetkowi głęboko wierzących (7\%) i, jak wynika z analiz, grupy te są w znacznej mierze tożsame.

Porównując opinie o związkach religii i moralności młodych Polaków i ogółu dorosłych (rys. 7), można dojść do wniosku, że młodzież w większym stopniu czerpie z pozareligijnych systemów wartości i źródeł moralności, ma więcej zastrzeżeń do zasad katolicyzmu i częściej odżegnuje się od nich. Widać w tym pewną niekonsekwencję postaw i wartości - przy wyższym niż wśród ogółu Polaków poziomie nacjonalizmu wśród młodych ${ }^{37}$, nieco dziwi umiłowanie dla nieograniczonej wolności i postępowania zgodnego wyłącznie z własnym sumieniem. Konstatacja ta nie dotyczy jednak osób głęboko wierzących, dla których religia w znacznej mierze jest źródłem moralności.

37 R. Boguszewski, A. Głowacki, Między patriotyzmem a nacjonalizmem, Komunikat z badań CBOS nr 151/2016. 


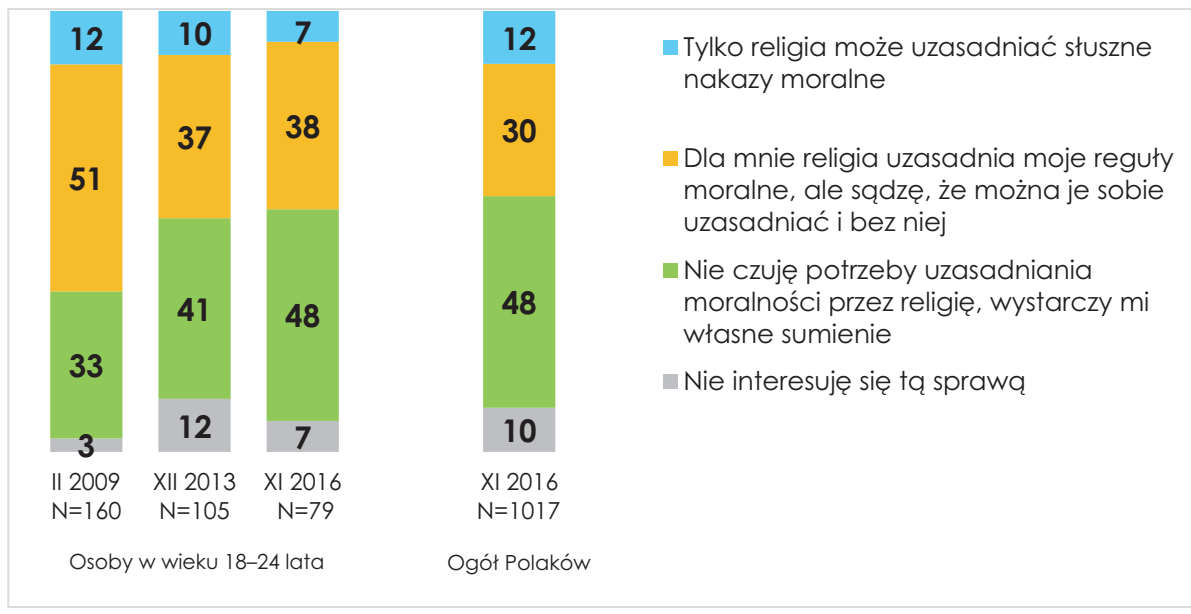

Rys. 7. Jaki jest Pana(i) stosunek do zasad moralnych religii katolickiej? Proszę wskazać tę odpowiedź, która najbliższa jest Pana(i) poglądom

Źródło: Opracowanie własne na podstawie: R. Boguszewski, Zasady moralne a religia, Komunikat z badań CBOS nr 4/2017.

\section{Wnioski}

Zaprezentowane dane dotyczące polskiej młodzieży wskazują na ewidentne przejawy sekularyzacji moralności, która wyraża się w tym, że młodzi Polacy w dość ograniczonym stopniu odczuwają potrzebę religijnego uzasadniania standardów moralnych (rzadziej niż ogół populacji) i w wielu sprawach deklarują poglądy moralne trudne do pogodzenia $\mathrm{z}$ religią. Zjawisko to dotyczy także tych przedstawicieli młodzieży, którzy określają się jako wierzący, a nawet głęboko wierzący. Stosunkowo często prezentowane selektywne podejście do zasad moralnych katolicyzmu oraz traktowanie ich jako moralności nie do końca przystającej do dzisiejszej rzeczywistości znajduje swoje wyraźne odzwierciedlenie w stosunku młodych Polaków przede wszystkim do takich kwestii i zachowań jak antykoncepcja, seks przedmałżeński, rozwód, zdrada czy aborcja.

Nie ulega wątpliwości, że zarówno zmiany w zakresie religijności, jak i moralności młodzieży podążają w kierunku coraz większej indywidualizacji (prywatyzacji) i deinstytucjonalizacji. Towarzyszy im wzrost permisywizmu i sytuacjonizmu. Szczególnie wyraźnie jest to widoczne w obszarze tzw. moralności osobistej - dotyczącej wartości i norm związanych ze sferą seksualno-małżeńską. Ten wymiar postaw i zachowań młodzieży w sposób dość jednoznaczny wskazuje na występujące od dawna i pogłębiające się rozdzielenie sfery moralnej od sfery religijnej. 
Należy też mieć jednak na względzie, że o ile przybywa niewierzących i nieuczestniczących w praktykach religijnych, odsetek głęboko wierzących i praktykujących kilka razy w tygodniu pozostaje stabilny, a dzięki większej konsekwencji w deklaracjach wiary i postaw moralnych korelacja obu postaw przybiera na sile, co może wskazywać z jednej strony na sekularyzację, ateizację $\mathrm{i}$ antyklerykalizm, a $\mathrm{z}$ drugiej na religijność bardziej uświadomioną, pogłębioną i konsekwentną. Zatem, zgodnie z sugestią Janusza Mariańskiego, współczesne przemiany w religijności i moralności Polaków, w tym także młodych, należy interpretować w świetle wielu teorii, nie tylko teorii sekularyzacji, ale i teorii indywidualizacji, deprywatyzacji, desekularyzacji, socjalizacji, globalizacji, ewangelizacji itp. Jeżeli nawet są one niekiedy postrzegane jako konkurencyjne, to każda z nich do pewnego stopnia skupia się na innych elementach życia religijnego. Dla pełniejszego zrozumienia niejednoznacznych postaw i zachowań religijnych ludzi współczesnych należy łączyć te różne perspektywy badawcze ${ }^{38}$.

Religia młodych słabnie wprawdzie, ale wbrew skrajnym teoriom sekularyzacyjnym nie umiera ${ }^{39}$, pozostaje w ustawicznym ruchu, przybiera rozmaite formy, adaptuje się do wymogów nowoczesności, zmienia się, globalnie tracąc ilościowo, ale w niektórych kręgach zyskując pod względem jakościowym ${ }^{40}$.

\section{Bibliografia}

Bell D., Powrót sacrum, Poznań 1983.

Berger P., Refleksje o dzisiejszej socjologii religii, „Teologia Polityczna” 2009-2010, nr 5.

Berger P., Święty baldachim. Elementy socjologicznej teorii religii, Kraków 2005.

Boguszewski R., Głowacki A., Między patriotyzmem a nacjonalizmem, Komunikat z badań CBOS nr 151/2016.

Boguszewski R., Codzienna aktywność Polaków. Autoportret i obraz środowiska społecznego w latach 1988-2018, Komunikat z badań CBOS nr 164/2018.

Boguszewski R., Religijność i moralność w społeczeństwie polskim: zależność czy autonomia? Studium socjologiczne, Toruń 2012.

Boguszewski R., Wartości i normy, Komunikat z badań CBOS nr 111/2013.

Boguszewski R., Zasady moralne a religia, Komunikat z badań CBOS nr 4/2017.

Bożewicz M., Boże Narodzenie 2019, Komunikat z badań CBOS nr 164/2019.

Głowacki A., Jakiego prawa aborcyjnego oczekują Polacy?, Komunikat z badań CBOS nr 144/2016. Głowacki A., Oceny sytuacji Kościoła katolickiego w Polsce, Komunikat z badań CBOS nr 101/2019. Grabowska M., Bóg a sprawa polska. Poza granicami teorii sekularyzacji, Warszawa 2018.

Grabowska M., Gwiazda M., Młodzież 2016, Opinie i Diagnozy nr 38, red. M. Grabowska, M. Gwiazda, Warszawa 2017.

38 Tamże, s. 34-35.

39 Wstępne dane CBOS za 2019 rok wskazują wręcz na pewne ożywienie w zakresie tradycyjnej religijności.

40 J. Mariański, S. Wargacki, Płynne sacrum w społeczeństwie ponowoczesnym, „Uniwersyteckie Czasopismo Socjologiczne" 2016, nr 4(17), s. 8. 
Grabowska M., Gwiazda M., Młodzież 2018, Opinie i Diagnozy nr 43, red. M. Grabowska, M. Gwiazda, Warszawa 2019.

Habermas J., Wierzyć i wiedzieć, „Znak” 2002, nr 568, tłum. M. Łukasiewicz.

Jan Paweł II, Encyklika «Veritatis splendor». O niektórych podstawowych problemach nauczania moralnego Kościoła, Watykan 1993.

Libiszowska-Żółtkowska M., Religijność i duchowość - dawne i nowe formy, Kraków 2010.

Libiszowska-Żółtkowska M., Wprowadzenie, w: Pomiędzy sekularyzacjq i religijnym ożywieniem, E. Firlit, M. Hainz, M. Libiszowska-Żółtkowska, G. Pickel, D. Pollack, Kraków 2012.

Mariański J., Religia i moralność w przednowoczesnych i nowoczesnych społeczeństwach, w: O społeczeństwie, moralności i nauce. Miscellanea, red. W. Pawlik, E. Zakrzewska-Manterys,

Warszawa 2008.

Mariański J., Religia i moralność we współczesnym świecie - utożsamianie czy rozdzielanie?, w: Scio cui credidi. Księga pamiątkowa ku czci Księdza Profesora Mariana Ruseckiego w 65.

rocznicę urodzin, red. I.S. Ledwoń, K. Kaucha i in., Lublin 2007.

Mariański J., Religijność w procesie przemian, Warszawa 1991.

Mariański J., Sekularyzacja a nowe formy religijności, „Roczniki Nauk Społecznych” 2009, t. 1(37).

Mariański J., Sekularyzacja i desekularyzacja w nowoczesnym świecie, Lublin 2006.

Mariański J., Socjologia moralności, Lublin 2006.

Mariański J., Wargacki S., Płynne sacrum w społeczeństwie ponowoczesnym, „Uniwersyteckie Czasopismo Socjologiczne" 2016, nr 4(17).

Parsons T., Struktura społeczna a osobowość, Warszawa 1969.

Słomski W., Człowiek pośród dylematów i wyzwań etycznych współczesności, Warszawa 2009.

Sztajer S., Założeniowość teorii przemian religijności, „Przegląd Religioznawczy” 2015, nr 1(255).

\section{Religijność i moralność polskiej młodzieży - zależność czy autonomia?}

\section{Streszczenie}

Artykuł, w oparciu o wyniki aktualnych badań empirycznych o charakterze ilościowym zrealizowanych na próbach ogólnopolskich, ale również w oparciu o wyniki cyklicznych badań prowadzonych wśród młodzieży kończącej edukację na poziomie szkół średnich, koncentruje się na przeobrażeniach w zakresie religijności i moralności polskiej młodzieży, umiejscawiając obserwowane trendy na płaszczyźnie socjologicznych teorii przemian religijności i jej związków z moralnością.

Słowa kluczowe: religijność, moralność, młodzież, sondaż, badania empiryczne, sekularyzacja

\section{Religiosity and morality of Polish youth - dependence or autonomy?}

\section{Abstract}

The article is based on the results of current empirical quantitative research carried out on national samples, but also on the results of cyclical research conducted among young people graduating from secondary schools, and focuses on the transformations in the area of religiousness and morality of Polish youth, placing the observed trends on the level of sociological theories of transformations of religiousness and its relation to morality.

Key words: religiosity, morality, youth, survey, empirical research, secularization 